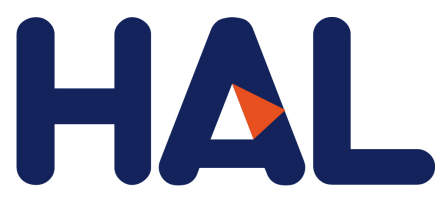

archives-ouvertes

\title{
Arthritis in primary Sjögren's syndrome: Characteristics, outcome and treatment from French multicenter retrospective study
}

Adrien Mirouse, Raphaele Seror, Eric Vicaut, Xavier Mariette, Maxime Dougados, Anne-Laure Fauchais, Alban Deroux, Azeddine Dellal, Nathalie

Costedoat-Chalumeau, Guillaume Denis, et al.

\section{To cite this version:}

Adrien Mirouse, Raphaele Seror, Eric Vicaut, Xavier Mariette, Maxime Dougados, et al.. Arthritis in primary Sjögren's syndrome: Characteristics, outcome and treatment from French multicenter retrospective study. Autoimmunity Reviews, Elsevier, 2019, 18 (1), pp.9-14. 10.1016/j.autrev.2018.06.015 . hal-02171337

\section{HAL Id: hal-02171337 \\ https://hal.sorbonne-universite.fr/hal-02171337}

Submitted on 29 Aug 2019

HAL is a multi-disciplinary open access archive for the deposit and dissemination of scientific research documents, whether they are published or not. The documents may come from teaching and research institutions in France or abroad, or from public or private research centers.
L'archive ouverte pluridisciplinaire HAL, est destinée au dépôt et à la diffusion de documents scientifiques de niveau recherche, publiés ou non, émanant des établissements d'enseignement et de recherche français ou étrangers, des laboratoires publics ou privés. 


\section{Arthritis in primary Sjögren's syndrome: characteristics, outcome and treatment from}

\section{French multicenter retrospective study}

Adrien Mirouse, M.D. ${ }^{1,2}$, Raphaèle Seror, M.D., Ph.D. ${ }^{3}$, Eric Vicaut M.D., Ph.D. ${ }^{4}$, Xavier Mariette M.D., Ph.D. , Maxime Dougados M.D. Ph.D. , Anne-Laure Fauchais M.D., Ph.D. , Alban Deroux M.D. Ph.D. , Azeddine Dellal, M.D. , Nathalie Costedoat-Chalumeau, M.D., Ph.D. ${ }^{7}{ }^{10,}$, Guillaume Denis, M.D. ${ }^{12}$, Jérémie Sellam, M.D., Ph.D. ${ }^{2,}$, Jean-Benoît Arlet, M.D. Ph.D. ${ }^{14}$, Christian Lavigne, M.D. ${ }^{15}$, Geoffrey Urbanski, M.D. ${ }^{15}$, Dominique Fischer-Dumont, M.D. ${ }^{16}$, Abdou Diallo $^{4}$, Olivier Fain, M.D. ${ }^{1,2}$, Arsène Mékinian, M.D., Ph.D. ${ }^{1,2}$, on behalf of Club Rhumatismes Inflammation and SNFMI.

${ }^{1}$ Service de médecine interne, Hôpital Saint-Antoine, APHP, Paris, France

2 DHU I2B: Inflammation, Immunopathologie, Biothérapie, Université Paris 06

3 Service de rhumatologie, Hôpital du Kremlin-Bicêtre, APHP, Bicêtre, France

${ }^{4}$ Service de biostatistiques médicales, Hôpital Lariboisière, APHP, France

5 Service de rhumatologie B, Hôpital Cochin, Paris, France

6 Service de médecine interne, CHU de Limoges, Limoges, France

7 Service de médecine interne, CHU Grenoble, La Tronche, France

8 Service de rhumatologie, Hôpital Montfermeil, Montfermeil, France

9 Service de médecine interne, centre de référence maladies auto-immunes et systémiques rares, Hôpital Cochin, APHP, Paris, France

10 Université Paris Descartes-Sorbonne Paris Cité, Paris, France

11 INSERM U 1153, Center for Epidemiology and Statistics Sorbonne Paris Cité (CRESS), Paris, France

12 Service de médecine interne, Hôpital de Rochefort, France

13 Service de rhumatologie, Hôpital Saint-Antoine, APHP, Paris, France 
14 Service de médecine interne, Hôpital Européen Georges Pompidou, APHP, Paris, France

15 Service de médecine interne, CHU Angers, Angers, France

16 Service de rhumatologie, Hôpital Avicenne, APHP, Bobigny, France

Correspondence and reprints to Arsène Mékinian, arsene.mekinian@aphp.fr

Conflicts and funding: none

Running title: Arthritis in Sjogren's syndrome

Words (2414) Abstracts (250) figures (1), tables (3) 


\begin{abstract}
Background

The aims of our study were to describe the characteristics and the outcome of primary Sjögren Syndrome (pSS) associated arthritis and to compare the efficacy of different therapeutic regimen, like hydroxychloroquine (HCQ), methotrexate (MTX) and rituximab (RTX).
\end{abstract}

\title{
Patients Methods
}

We conducted a retrospective study using Club Rhumatisme and Inflammation (CRI) and French Internal Medicine Society (SNFMI) networks. All patients with a diagnosis of primary Sjögren’s Syndrome (pSS) and at least one clinical and/or echographic synovitis were included. Patients with synovitis (cases) were compared to pSS patients without synovitis (controls).

\section{Results}

57 patients (93\% women) were included with a median age of 54 years [45-63]. Patients with synovitis had more frequently lymph node enlargement $(12.3 \%$ vs. $1.8 \%, \mathrm{p}=0.007)$. There was no difference concerning other pSS systemic manifestations, CRP levels, rheumatoid factor and CCPantibodies positivity. Among 57 patients with synovitis, 101 lines of various treatments have been used during the follow-up of 40 [22.5-77] months. First line treatment consisted in steroids alone (3.5\%), steroids in association (79\%) with HCQ (49\%), MTX (35\%), RTX (5.3\%) or other immunosuppressive drugs (7\%). HCQ, MTX, and RTX were associated with a significant reduction of tender and swollen joint count, and a significant steroids-sparing effect. No difference could be shown for the joint response between these treatment regimens.

\section{Conclusion}

pSS articular manifestations may include synovitis which could mimic rheumatoid arthritis but differ by the absence of structural damage. Even if the use of HCQ, MTX, and RTX seem to be effective for joint involvement, the best regimen remains to be determined. 


\section{Introduction}

Primary Sjogren's syndrome (pSS) is a chronic inflammatory disorder characterized by diminished lacrimal and salivary gland functions. The histological hallmark is a focal lymphocytic infiltration of the salivary gland, and the spectrum of the disease may extend to a systemic process with vasculitis and diverse extra-glandular systemic manifestations. Beside the glandular disease, joint involvement is reported in 20 to $60 \%$ of pSS patients, and among them one third of patients present synovitis (1-3). Despite the presence of anti-Citrullinated-Peptide Antibodies (ACPA) in 5 to $10 \%$ of pSS, but there is usually no joint erosion during the course of pSS (4-6). However, in at least half of these cases with ACPA, there was an evolution towards rheumatoid arthritis (RA) (7).

Arthralgia and synovitis have been described as associated with other pSS inflammatory manifestations like recurrent parotidomegaly, cutaneous vasculitis, or cryoglobulinemia (8-10). Few studies reported the efficacy of various treatments for joint involvement, but there is a lack of data concerning therapeutic management during pSS-associated synovitis. Hydroxychloroquine (HCQ) and methotrexate (MTX) efficacy has been reported in patients with pSS and joint involvement but, among them, only 35\% have clinical synovitis (2). Another study including only 19 patients with joint involvement showed no efficacy of HCQ (11). Biologic drugs, including TNF $\alpha$ inhibitors and Rituximab (RTX), have been studied in pSS and failed to improve glandular symptoms and constitutional signs (12-17). However, RTX could improve some extraglandular systemic features, like neurological involvement and joint pain, but no studies focused on pSSassociated inflammatory arthritis (18).

The aims of our study were to describe the characteristics and the outcome of pSS-associated arthritis and to compare the efficacy of different therapeutic regimen, like HCQ, MTX and RTX.

\section{Patients and methods:}

We conducted a multicentric retrospective study using the "French Inflammatory Joint Disease 
Working Group" (Club Rhumatismes et Inflammation) and the "French Internal Medicine Society" (SNFMI) networks. All physicians were asked to fulfill charts. This study was conducted in compliance with the protocol of Good Clinical Practices and Declaration of Helsinki principles. In accordance with French law, formal approval from an ethical committee was not required for this observational retrospective study.

\section{Inclusion criteria:}

All patients ( $\geq 18$ years) with a diagnosis of primary Sjögren-Syndrome (pSS) (American-European Consensus Group-AECG criteria) and at least one clinical and/or ultrasound synovitis during the follow-up were included among 13 French Internal Medicine and Rheumatology departments (19). Patients were identified from hospital databases using code M35.0 and M65.0 from the International Classification of Diseases (ICD-10). Patients with other diagnosis of inflammatory (p.e ACR-EULAR criteria for rheumatoid arthritis) (20), infectious or microcrystalline arthritis (gout, chondrocalcinosis) were excluded. All patients' medical records were reviewed by 2 investigators (A Mi and $\mathrm{A} \mathrm{Me})$.

\section{Data collection:}

Following data were recorded from patients' medical charts: age, sex, diagnosis date, the presence of ocular and oral subjective and objective symptoms, extra-articular signs including constitutional manifestations, lymphadenopathy, glandular involvement, cutaneous, pulmonary, renal, muscular, and neurological manifestations. Articular manifestations included the number of tender and swollen joints, type of joints involved and the presence of morning stiffness. Synovitis was diagnosed with clinical examination and/or with joint ultrasonography. Articular and other pSS manifestations were collected at the diagnosis, at each therapeutic line initiation, and the last available visit. Disease activity was assessed using EULAR Sjögren Syndrome Disease Activity Index (ESSDAI), at the inclusion and during the follow-up (21).

Biological data at the diagnosis, including complete blood cell count, immunological tests (Anti- 
Nuclear Antibodies [ANA], Extractable Nuclear Antibodies [ENA] Rheumatoid Factor [RF], Cyclic Citrullinated Peptide [CCP] antibodies, complement and cryoglobulinemia). C-reactive protein (CRP) levels were collected at the inclusion and during the follow-up. Radiological findings were recorded, especially the presence of erosions.

Indication for treatment initiation was recorded and defined as either for articular manifestations or other pSS manifestations. All therapeutic lines were recorded, including Non-Steroidal AntiInflammatory Drugs (NSAIDs), steroids, HCQ, MTX, RTX and other disease-modifying antirheumatic drugs (DMARDs) and biological-targeted treatments. Steroids dose was collected at the inclusion and during the follow-up. Treatment initiation and each line end dates were recorded.

A control group of pSS patients without any synovitis was selected from the rheumatology department Kremlin-Bicêtre hospital pSS cohort to determine the factors associated with joint involvement. Two controls were included for each pSS patient with arthritis and matched for age ( \pm 10 years $)$, gender and $\mathrm{pSS}$ disease duration.

Treatment response was assessed for each treatment line. Complete treatment response was defined for joint involvement as disappearance of all arthralgia and synovitis. Partial response was defined as improvement of more than $50 \%$ of the swollen joint count (i.e. number of synovitis) and nonresponse in remaining cases. ESSDAI scale and C-reactive protein levels were also assessed before and at the end of each treatment regimen. Reasons for treatment interruption were collected and defined as remission, inefficacity, relapse or adverse side effect.

\section{Statistical analysis}

Data are expressed as medians with interquartiles range and numbers with frequencies. To compare the quantitative values, parametrical t-test or non-parametrical Mann Whitney tests were used as appropriate. To compare qualitative values, chi-square tests or Fischer's exact tests were used for parametrical and non-parametrical values, respectively. To assess the efficacy of each treatment, all patients' treatment lines were analyzed and used to compare the efficacy of various drugs. 
Propensity scores were used to determine the odds ratio of each treatment response for joint involvement. All analyses were done using R version 3.0.2 (R Core Team (2015) and p value less than 0.05 was considered as significant.

\section{Results:}

pSS patients with synovitis

During the study period, 57 patients (93\% women) were included with a median age at pSS related synovitis diagnosis of 54 years [45-63] (Table 1). Subjective xerophtalmia and xerostomia were noted in 54 (94\%) and $55(97 \%)$, respectively. A lymphocytic sialadenitis was present at salivary gland biopsy for $44(78.6 \%)$ patients. All (100\%) patients had at least one clinical synovitis. Twenty-nine $(51 \%)$ patients had a joint evaluation with ultrasound $(n=23)$ or Magnetic Resonance Imagery (MRI) $(n=6)$ which confirmed clinical synovitis for all patients. At the time of diagnosis of joint manifestations, the main pattern was a symmetric polyarthritis $(n=39,67 \%)$, touching metacarpophalangeal joints in $36(68 \%)$ cases and proximal interphalangeal joints in $30(57 \%)$ cases. Median number of tender and swollen joints at the diagnosis was 8 [4-12] and 4 [2-6], respectively. Median morning stiffness was 30 [30-60] minutes and 45 (82\%) patients reported night awakening. Laboratory findings showed median CRP level at 5 [3-9.3] mg/l. Beta-2microglobulin level was 3.03 [1.99-3.92] mg/l. Median gammaglobulin level was 14.0 [12.0-18.8] g/l. ANA levels were at 1/640 [1/160-1/1280] with SSa and SSb specificity in 42 (78\%) and 19 (37\%), respectively. Twenty-two (45\%) patients had rheumatoid factor positivity and $6(10.5 \%)$ patients had CCP-antibodies positivity (median 114 [16-148] UI/l). A cryoglobulinemia was detected in $3(5 \%)$ patients. Initial median ESSDAI score was 8 [6-12]. Sixteen (28\%) patients, including all 6 patients with ACPA, had radiological evaluation at the end of follow-up (32.5 [22.549.8] months), and no patient had structural damage. 
During the same study period, we identified 114 pSS patients without synovitis which represent the control group and were compared to pSS patients with synovitis. pSS patients' characteristics with and without synovitis are described in Table 1. Subjective xerostomia and xerophtalmia frequencies were similar in both groups, whereas objective xerophtalmia and xerostomia and parotid enlargement were more frequent in patients without synovitis. Patients with synovitis had more frequently lymph nodes enlargement $(12.3 \%$ vs. $1.8 \%, \mathrm{p}=0.007)$. There was no difference concerning other pSS systemic manifestations. Patients from the 2 groups did not differ regarding acute-phase reactants, nor RF positivity (Table 1). Patients with synovitis had a trend toward a higher ACPA positivity (14\% vs. $2.7 \%, \mathrm{p}=0.06)$.

Regarding treatments, patients with synovitis were treated more frequently with steroids (43 [75\%] vs. 7 [6\%], p<0.0001), MTX (21 [37\%] vs. 1 [0.08\%], p<0.0001) and HCQ (38 [67\%] vs. 17 [15\%], $\mathrm{p}<0.0001)$. There was no difference concerning the frequencies of NSAID use.

\section{Treatments of pSS with synovitis}

Among 57 patients with synovitis, 101 lines of various treatments have been used during the follow-up of 40 [22.5-77] months (Figure 1). All patients received at least one therapeutic line, the first line consisted in steroids alone (3.5\%), HCQ (49\%), MTX (35\%), RTX (5.3\%) or other immunosuppressive drugs (7\%). Treatment was initiated for joint involvement in $53(93 \%)$ patients and the first-line median duration was of 5 [3-8] months. No clinical and biological finding did influence the first-line treatment choice. A second therapeutic line was initiated in $31(54.4 \%)$ cases, for relapse $(n=6)$, treatment failure $(n=16)$ or adverse side effect $(n=9)$ and consisted in steroids alone (3\%), HCQ (19\%), MTX (29\%), RTX (32\%) or other immunosuppressive drug (16\%). The second-line median duration was of 8 [6-10] months. Thirteen patients $(22.8 \%)$ received a third line treatment, for relapse $(n=3)$, treatment failure $(n=5)$ or adverse side effect $(n=5)$ and consisted in steroids alone (8\%), MTX (23\%), RTX (46\%) or other immunosuppressive drug (23\%). The thirdline median duration was of 7 [3.3-9.7] months.

Comparison between HCQ, MTX, and RTX considering all 101 therapeutic lines is reported in 
Table 2. At baseline, the number of tender and swollen joint counts tended to be more important before HCQ and MTX in comparison to RTX initiation, whereas ESSDAI and C-reactive protein levels were similar (Table 2). Only HCQ treatment was associated with a decrease in tender (0 vs. 7 [3-10] at baseline; $\mathrm{p}=0.0004)$ and swollen $(0[0-1]$ vs. $2[1-5]$ at baseline; $\mathrm{p}<0.0001)$ joint counts. Partial and/or complete joint response was showed in 9/18 (50\%) lines of MTX, 24/38 (63\%) of lines of HCQ and 14/19 lines (74\%) of RTX, whereas complete joint response were quite similar with 3 regimens (22\% vs $32 \%$ and $21 \%$, respectively). The number of complete/partial joint responses significantly increased considering the number of overall lines of treatment for MTX, HCQ and RTX: $52 \%$ for the first line, $76 \%$ for the second line and $83 \%$ for the $3 \mathrm{e}$ line $(\mathrm{p}<0.05)$, and data were similar considering each drug separately. There was no difference of efficacy between HCQ, MTX, and RTX concerning tender and swollen joint count, CRP level, ESSDAI score and steroids sparing effect at the end of each drug regimen. We performed a propensity score based analysis to determine whether HCQ, MTX, or RTX treatment was associated with better joint outcome. No difference could be shown for the joint response between three treatment regimen (MTX vs. HCQ, OR 1.55 [0.18-13.55], p=0.69; MTX vs. RTX, OR 5.08 [0.49-52.17], p=0.17; HCQ vs. RTX OR 3.28 [0.28-38.02], p=0.34). All 3 treatment (HCQ, MTX, and RTX) were associated with a significant reduction of ESSDAI score and a significant steroids-sparing effect (Table 2).

\section{Discussion:}

As far as we know, this is the largest study of patients with pSS-synovitis, which report clinical, biological and radiological features, outcome and treatment of 57 patients. Main presentation was a peripheral symmetric polyarthritis and patients with synovitis presented more frequently lymph node enlargement. HCQ, MTX, and RTX were associated with a significant reduction of ESSDAI score and showed similar efficacy for joint involvement. Despite frequent presence of RF and ACPA, no structural progression was observed during follow-up in patients who had an X-ray 
evaluation, including all patients with ACPA.

Compared with patients without articular manifestations, patients with synovitis presented more frequently lymph node enlargement, which might be a sign of B-Cell chronic activation. Systemic manifestations in pSS have already been related to articular manifestations (2). However, there was no difference concerning CRP level, ESR, gamma-globulin level. In our study, there was a tendency toward a higher prevalence of ACPA in patients with synovitis, as it has already been reported $(1,22,5)$. It could be argued that our patients with ACPA had RA with associated Sjögren's syndrome (sSS), but we found similar prevalence of RF and ACPA compared to other pSS studies and no erosions occurred during the follow-up $(4,5,27)$.

There is no consensual treatment for pSS, especially for articular manifestations and no study specifically addressed the treatment efficacy for joint involvement with synovitis. One study reported no effect of HCQ on articular manifestations in pSS, but synovitis status was not analyzed (11). Another double blinded controlled randomized trial showed no difference between HCQ and placebo concerning dryness, pain and fatigue and ESSDAI score, but only few patients with inflammatory joint involvement and synovitis have been included (28). One pilot study suggested that tumor necrosis factor inhibitor (infliximab) might be beneficial, but subsequent multicenter trials did not confirm these results $(12,13,29,30)$. Only few patients with joint involvement have been analyzed in these studies. Some studies suggested that RTX could be efficient on pSS joint involvement (17,31). A recent meta-analysis of RTX in pSS showed efficacy of RTX compared to placebo concerning salivary flow rate (32). All those studies were not designed to specifically study the effect of treatment on articular manifestations and/or synovitis. In our study, HCQ, MTX and RTX were efficient to control articular manifestations, including synovitis, reduced ESSDAI score and spare steroids use. These data are in line with real-life registries of pSS, which reported significant improvement of ESSDAI, and neurological and joint involvements $(16,17)$. Promising data have been recently reported with BAFF inhibitor, belimumab, but only few patients with synovitis have been included in these studies and in our series the number of pSS under belimumab 
was too low to analyze its efficacy $(33,34)$.

Our study has several biases which could limit definitive conclusions. First of all, it is a retrospective study and there might be some limits due to missing data. However, our patients' general characteristics do not differ from what has already been described in the literature for pSS patients. Evaluation of treatment efficacy was not randomized and blinded and we considered all treatments lines to analyze the various regimens. Sjögren patients without arthritis were selected from one center (Kremlin-Bicetre Hospital) which could induce some bias of selection and thus we could not evaluate the real prevalence of Sjögren related arthritis. We tried to limit this effect performing a propensity score based analysis, which recently was described for the analysis of series with low patient number. Even well-designed studies are necessary to assess our findings, this first study addressing the efficacy on synovitis in pSS provides data for various treatments efficacies in this specific patient subset, and in particular addresses the steroid sparing effect of different strategies.

In conclusion, pSS articular manifestations may include synovitis which could mimic rheumatoid arthritis, but differ by the absence of structural damage. Even the use of HCQ, MTX and RTX seem to be effective for joint involvement, the best regimen remains to be determined. Only double-blind randomized controlled trial could determine this best regimen for these specific pSS subset. 


\section{References:}

1. Castro-Poltronieri A, Alarcón-Segovia D. Articular manifestations of primary Sjögren's syndrome. J Rheumatol. 1983 Jun;10(3):485-8.

2. Fauchais A-L, Ouattara B, Gondran G, Lalloué F, Petit D, Ly K, et al. Articular manifestations in primary Sjögren's syndrome: clinical significance and prognosis of 188 patients. Rheumatol Oxf Engl. 2010 Jun;49(6):1164-72.

3. Gottenberg J-E, Seror R, Miceli-Richard C, Benessiano J, Devauchelle-Pensec V, Dieude P, et al. Serum Levels of Beta2-Microglobulin and Free Light Chains of Immunoglobulins Are Associated with Systemic Disease Activity in Primary Sjögren's Syndrome. Data at Enrollment in the Prospective ASSESS Cohort. PLOS ONE. 2013 mai;8(5):e59868.

4. Gottenberg J-E, Mignot S, Nicaise-Rolland P, Cohen-Solal J, Aucouturier F, Goetz J, et al. Prevalence of anti-cyclic citrullinated peptide and anti-keratin antibodies in patients with primary Sjögren's syndrome. Ann Rheum Dis. 2005 Jan;64(1):114-7.

5. Atzeni F, Sarzi-Puttini P, Lama N, Bonacci E, Bobbio-Pallavicini F, Montecucco C, et al. Anti-cyclic citrullinated peptide antibodies in primary Sjögren syndrome may be associated with non-erosive synovitis. Arthritis Res Ther. 2008;10(3):R51.

6. Kyriakidis NC, Kapsogeorgou EK, Tzioufas AG. A comprehensive review of autoantibodies in primary Sjögren's syndrome: clinical phenotypes and regulatory mechanisms. J Autoimmun. 2014 Jun;51:67-74.

7. Payet J, Belkhir R, Gottenberg JE, Bergé E, Desmoulins F, Meyer O, et al. ACPA-positive primary Sjögren's syndrome: true primary or rheumatoid arthritis-associated Sjögren's syndrome? RMD Open. 2015;1(1):e000066.

8. Pease CT, Shattles W, Barrett NK, Maini RN. The arthropathy of Sjögren's syndrome. Br J Rheumatol. 1993 Jul;32(7):609-13.

9. Ramos-Casals M, Anaya J-M, García-Carrasco M, Rosas J, Bové A, Claver G, et al. Cutaneous vasculitis in primary Sjögren syndrome: classification and clinical significance of 52 patients. Medicine (Baltimore). 2004 Mar;83(2):96-106.

10. Ramos-Casals M, Cervera R, Yagüe J, García-Carrasco M, Trejo O, Jiménez S, et al. Cryoglobulinemia in primary Sjögren's syndrome: prevalence and clinical characteristics in a series of 115 patients. Semin Arthritis Rheum. 1998 Dec;28(3):200-5.

11. Kruize AA, Hené RJ, Kallenberg CG, Bijsterveld OP van, Heide A van der, Kater L, et al. Hydroxychloroquine treatment for primary Sjögren's syndrome: a two year double blind crossover trial. Ann Rheum Dis. 1993 May 1;52(5):360-4.

12. Mariette X, Ravaud P, Steinfeld S, Baron G, Goetz J, Hachulla E, et al. Inefficacy of infliximab in primary Sjögren's syndrome: results of the randomized, controlled Trial of Remicade in Primary Sjögren's Syndrome (TRIPSS). Arthritis Rheum. 2004 Apr;50(4):1270-6.

13. Sankar V, Brennan MT, Kok MR, Leakan RA, Smith JA, Manny J, et al. Etanercept in Sjögren's syndrome: a twelve-week randomized, double-blind, placebo-controlled pilot clinical trial. Arthritis Rheum. 2004 Jul;50(7):2240-5.

14. Devauchelle-Pensec V, Mariette X, Jousse-Joulin S, Berthelot J-M, Perdriger A, Puéchal X, et al. Treatment of primary Sjögren syndrome with rituximab: a randomized trial. Ann Intern Med. 2014 Feb 18;160(4):233-42.

15. Mekinian A, Ravaud P, Larroche C, Hachulla E, Gombert B, Blanchard-Delaunay C, et al. Rituximab in central nervous system manifestations of patients with primary Sjögren's syndrome: results from the AIR registry. Clin Exp Rheumatol. 2012 Apr;30(2):208-12.

16. Mekinian A, Ravaud P, Hatron PY, Larroche C, Leone J, Gombert B, et al. Efficacy of rituximab in primary Sjogren's syndrome with peripheral nervous system involvement: results from the AIR registry. Ann Rheum Dis. 2012 Jan;71(1):84-7.

17. Gottenberg J-E, Cinquetti G, Larroche C, Combe B, Hachulla E, Meyer O, et al. Efficacy of rituximab in systemic manifestations of primary Sjogren's syndrome: results in 78 patients of the AutoImmune and Rituximab registry. Ann Rheum Dis. 2013 Jun;72(6):1026-31. 
18. Moerman RV, Arends S, Meiners PM, Vissink A, Spijkervet FKL, Kroese FGM, et al. Detailed Analysis of the Articular Domain in Patients with Primary Sjögren Syndrome. J Rheumatol. 2017 Mar 1;44(3):292-6.

19. Vitali C, Bombardieri S, Jonsson R, Moutsopoulos HM, Alexander EL, Carsons SE, et al. Classification criteria for Sjögren's syndrome: a revised version of the European criteria proposed by the American-European Consensus Group. Ann Rheum Dis. 2002 Jun;61(6):554-8.

20. Aletaha D, Neogi T, Silman AJ, Funovits J, Felson DT, Bingham CO, et al. 2010 Rheumatoid arthritis classification criteria: An American College of Rheumatology/European League Against Rheumatism collaborative initiative. Arthritis Rheum. 2010 Sep 1;62(9):2569-81.

21. Seror R, Ravaud P, Bowman SJ, Baron G, Tzioufas A, Theander E, et al. EULAR Sjogren's syndrome disease activity index: development of a consensus systemic disease activity index for primary Sjogren's syndrome. Ann Rheum Dis. 2010 Jun;69(6):1103-9.

22. ter Borg EJ, Kelder JC. Polyarthritis in primary Sjögren's syndrome represents a distinct subset with less pronounced B cell proliferation a Dutch cohort with long-term follow-up. Clin Rheumatol. 2016 Mar;35(3):649-55.

23. Lazarus MN, Isenberg DA. Development of additional autoimmune diseases in a population of patients with primary Sjögren's syndrome. Ann Rheum Dis. 2005 Jul;64(7):1062-4.

24. Iagnocco A, Modesti M, Priori R, Alessandri C, Perella C, Takanen S, et al. Subclinical synovitis in primary Sjögren's syndrome: an ultrasonographic study. Rheumatol Oxf Engl. 2010 Jun;49(6):1153-7.

25. Díaz-López C, Geli C, Corominas H, Malat N, Diaz-Torner C, Llobet JM, et al. Are there clinical or serological differences between male and female patients with primary Sjögren's syndrome? J Rheumatol. 2004 Jul;31(7):1352-5.

26. Pertovaara M, Pukkala E, Laippala P, Miettinen A, Pasternack A. A longitudinal cohort study of Finnish patients with primary Sjögren's syndrome: clinical, immunological, and epidemiological aspects. Ann Rheum Dis. 2001 May;60(5):467-72.

27. Tobón GJ, Correa PA, Anaya J-M. Anti-cyclic citrullinated peptide antibodies in patients with primary Sjögren's syndrome. Ann Rheum Dis. 2005 May 1;64(5):791-2.

28. Gottenberg J-E, Ravaud P, Puéchal X, Le Guern V, Sibilia J, Goeb V, et al. Effects of hydroxychloroquine on symptomatic improvement in primary Sjögren syndrome: the JOQUER randomized clinical trial. JAMA. 2014 Jul 16;312(3):249-58.

29. Steinfeld SD, Demols P, Salmon I, Kiss R, Appelboom T. Infliximab in patients with primary Sjögren's syndrome: a pilot study. Arthritis Rheum. 2001 Oct;44(10):2371-5.

30. Zandbelt MM, de Wilde P, van Damme P, Hoyng CB, van de Putte L, van den Hoogen F. Etanercept in the treatment of patients with primary Sjögren's syndrome: a pilot study. J Rheumatol. 2004 Jan;31(1):96-101.

31. Dass S, Bowman SJ, Vital EM, Ikeda K, Pease CT, Hamburger J, et al. Reduction of fatigue in Sjögren syndrome with rituximab: results of a randomised, double-blind, placebo-controlled pilot study. Ann Rheum Dis. 2008 Nov 1;67(11):1541-4.

32. Souza FB do V, Porfírio GJM, Andriolo BNG, Albuquerque JV de, Trevisani VFM. Rituximab Effectiveness and Safety for Treating Primary Sjögren's Syndrome (pSS): Systematic Review and Meta-Analysis. PloS One. 2016;11(3):e0150749.

33. Mariette X, Seror R, Quartuccio L, Baron G, Salvin S, Fabris M, et al. Efficacy and safety of belimumab in primary Sjögren's syndrome: results of the BELISS open-label phase II study. Ann Rheum Dis. 2015 Mar;74(3):526-31.

34. De Vita S, Quartuccio L, Seror R, Salvin S, Ravaud P, Fabris M, et al. Efficacy and safety of belimumab given for 12 months in primary Sjögren's syndrome: the BELISS open-label phase II study. Rheumatol Oxf Engl. 2015 Dec;54(12):2249-56. 


\section{TABLES}

Table 1: Characteristics of pSS patients with or without synovitis

\begin{tabular}{|c|c|c|c|}
\hline & $\begin{array}{c}\text { Joint involvement } \\
\mathbf{N}=57\end{array}$ & $\begin{array}{c}\begin{array}{c}\text { Without joint } \\
\text { involvement } \\
N=114\end{array} \\
\end{array}$ & $\mathbf{p}$ \\
\hline Diagnosis age (years) & $54[23-81]$ & $55[18-81]$ & 0.05 \\
\hline Sex, man & $4(7.0 \%)$ & $4(3.5 \%)$ & 0.4 \\
\hline Disease duration (months) & $8[4-23]$ & $10[5-26.8]$ & 0.47 \\
\hline $\begin{array}{c}\text { Xerophtalmia } \\
\text { Subjective } \\
\text { objective }\end{array}$ & $\begin{array}{l}54(94.7 \%) \\
34(60.7 \%)\end{array}$ & $\begin{array}{l}101(88.6 \%) \\
101(88.6 \%)\end{array}$ & $\begin{array}{c}0.3 \\
<0.0001 \\
\end{array}$ \\
\hline $\begin{array}{l}\text { Xerostomia } \\
\text { Subjective } \\
\text { objective }\end{array}$ & $\begin{array}{l}55(96.5 \%) \\
24(42.9 \%)\end{array}$ & $\begin{array}{l}107(93.4 \%) \\
108(94.7 \%)\end{array}$ & $\begin{array}{c}0.4 \\
<0.0001\end{array}$ \\
\hline Chisholm III/IV & $44(78.6 \%)$ & $88(77.9 \%)$ & 0.4 \\
\hline Parotiditis & $9(15.8 \%)$ & $41(40.0 \%)$ & 0.007 \\
\hline $\begin{array}{l}\text { Joint pain } \\
\text { Synovitis }\end{array}$ & $\begin{array}{c}57(100 \%) \\
4(2-6)\end{array}$ & $\begin{array}{c}83(\%) \\
-\end{array}$ & $<0.0001$ \\
\hline $\begin{array}{c}\text { Skin } \\
\text { Kidney } \\
\text { Lung involvement }\end{array}$ & $\begin{array}{l}12(21.2 \%) \\
1(1.8 \%) \\
6(10.5 \%)\end{array}$ & $\begin{array}{c}34(29.8 \%) \\
0(0 \%) \\
3(2.6 \%)\end{array}$ & $\begin{array}{c}0.3 \\
0.4 \\
0.06\end{array}$ \\
\hline $\begin{array}{c}\text { Peripheral nervous system } \\
\text { Central neurological involvement }\end{array}$ & $\begin{array}{l}7(12.3 \%) \\
1(1.8 \%)\end{array}$ & $\begin{array}{l}7(6.1 \%) \\
1(0.9 \%)\end{array}$ & $\begin{array}{l}0.2 \\
0.3\end{array}$ \\
\hline Myositis & $1(1.8 \%)$ & $2(1.8 \%)$ & 0.2 \\
\hline $\begin{array}{c}\text { Lymphadenopathy, n (\%) } \\
\text { Lymphoma, n (\%) }\end{array}$ & $\begin{array}{c}7(12.3 \%) \\
1(1.8 \%)\end{array}$ & $\begin{array}{l}2(1.8 \%) \\
0(0 \%)\end{array}$ & $\begin{array}{c}0.007 \\
0.3\end{array}$ \\
\hline Hemoglobin $(\mathrm{g} / \mathrm{dl})$ & $13[11.8-13.5]$ & $13.1[11.9-14.3]$ & 0.2 \\
\hline Platelets (G/l) & 239 [205-280] & $266[228.5-317.5]$ & 0.2 \\
\hline Neutrophils (G/l) & $4.2[2,9-5.3]$ & $2.96[2.24-3.81]$ & 0.002 \\
\hline Lymphocytes (G/l) & $1.9[0.9-2.3]$ & $1.54[1.27-2.01]$ & 0.2 \\
\hline Gammaglobulins (g/l) & $14[12-18.8]$ & $14[10.8-17.1]$ & 0.5 \\
\hline Monoclonal gammapathy, yes (\%) & $1(2.1 \%)$ & $6(5.3 \%)$ & 0.4 \\
\hline ESR (mm per hour), median[IQR] & 19 [11.5-35] & $18[9.5-28.5]$ & 0.2 \\
\hline CRP (mg/l) & $5[3-9.25]$ & $5[5-6]$ & 0.06 \\
\hline $\begin{array}{l}\text { ANA } \\
\text { SSa } \\
\text { SSb }\end{array}$ & $\begin{array}{c}640[1601280] \\
42(77.8 \%) \\
19(36.5 \%)\end{array}$ & $\begin{array}{l}640[0-1280] \\
81(71 \%) \\
45(39.4 \%)\end{array}$ & 0.7 \\
\hline $\mathbf{C 3}$ & $1.02[0.86-1.19]$ & $1.07[0.96-1.25]$ & 0.4 \\
\hline $\mathrm{C} 4$ & $0.24[0.12-0.32]$ & $0.21[0.17-0.26]$ & 0.4 \\
\hline Cryoglobulinemia & $3(5.3 \%)$ & $1(0.9 \%)$ & 0.1 \\
\hline RF & $22(44.9 \%)$ & $36(31.9 \%)$ & 0.4 \\
\hline ACPA & $6(10.5 \%)$ & $3(2.7 \%)$ & 0.06 \\
\hline B2 (mg/l) & $3.03[1.99-3.92]$ & $2.12[1.77-2.61]$ & 0.06 \\
\hline ESSDAI, median (IQR) & $8[6-12]$ & & - \\
\hline NSAID & $12(21 \%)$ & $22(19 \%)$ & 0.8 \\
\hline Methotrexate & $21(37 \%)$ & $1(0.08 \%)$ & $<0.0001$ \\
\hline Steroids (\%) / amount (mg/day) & $43(75 \%) / 10$ [9.4-15] & $7(6 \%) /-$ & $<0.0001$ \\
\hline Hydroxychloroquine & $38(67 \%)$ & $17(15 \%)$ & $<0.0001$ \\
\hline
\end{tabular}


Values are medians with interquartiles and numbers with frequencies

Abbreviations: ACPA: Anti-Citrulinated Peptide Antibodies, ANA: Anti-Nuclear Antibodies, CRP:

C - reactive protein, ESR: Erythrocyte Sedimentation Rate, ESSDAI: EULAR Sjögren Syndrome

Disease Activity Index, NSAID: Non-steroidal anti-inflammatory drugs, RF: Rheumatoid Factor 
Table 2: Comparison of joint response, ESSDAI and steroids dose at the initiation and the end of various therapeutic lines.

\begin{tabular}{|c|c|c|c|c|c|}
\hline Characteristics & $\begin{array}{l}\text { All lines } \\
\mathrm{N}=\mathbf{1 0 1}\end{array}$ & $\begin{array}{l}\text { HCQ } \\
\mathrm{N}=35\end{array}$ & $\begin{array}{l}\text { Methotrexate } \\
\quad \mathbf{N}=17\end{array}$ & $\begin{array}{l}\text { RTX } \\
\text { N=19 }\end{array}$ & $\begin{array}{c}\text { p-value } \\
\text { between } \\
\text { HCQ, } \\
\text { MTX, RTX } \\
\text { groups } \\
\text { (ANOVA) }\end{array}$ \\
\hline $\begin{array}{l}\text { Tender joint count } \\
\text { Before / at the end }\end{array}$ & $\begin{array}{c}5(1-10) \\
1(0-4)\end{array}$ & $\begin{array}{c}7(3-10) \\
0(0-4) \\
(* \mathrm{p}=0.0004)\end{array}$ & $\begin{array}{c}7(4-14) \\
4(1-6) \\
(* \mathrm{p}=0.07)\end{array}$ & $\begin{array}{c}3(0-6) \\
1.5(0-5.5) \\
(* \mathrm{p}=0.3)\end{array}$ & 0.07 \\
\hline $\begin{array}{l}\text { Swollen joint count } \\
\text { Before / at the end }\end{array}$ & $\begin{array}{c}2(1-5) \\
0(0-1.2)\end{array}$ & $\begin{array}{c}2(1-5) \\
0(0-1) \\
(* \mathrm{p}<0.0001)\end{array}$ & $\begin{array}{c}3.5(1-4) \\
0(0-1) \\
(* \mathrm{p}=0.3)\end{array}$ & $\begin{array}{c}1(0-3) \\
0.5(0-2) \\
(* \mathrm{p}=0.5)\end{array}$ & 0.07 \\
\hline $\begin{array}{c}\text { CRP (mg/l) } \\
\text { Before / at the end }\end{array}$ & $\begin{array}{c}5(3-7) \\
3(1.3-5)\end{array}$ & $\begin{array}{c}5(3-6) \\
4(2-5) \\
(* \mathrm{p}=0.4)\end{array}$ & $\begin{array}{c}5(3-18) \\
5(2-7) \\
(* \mathrm{p}=0.5)\end{array}$ & $\begin{array}{c}4(5-8) \\
3(1-4) \\
(* \mathrm{p}=0.1)\end{array}$ & 0.6 \\
\hline $\begin{array}{c}\text { ESSDAI } \\
\text { Before / at the end }\end{array}$ & $\begin{array}{l}6(4-10) \\
4(2-6)\end{array}$ & $\begin{array}{c}6(4-10) \\
3(0-4) \\
(* \mathrm{p}<0.0001)\end{array}$ & $\begin{array}{c}6(4-11) \\
4(2-6) \\
(* \mathrm{p}=0.01)\end{array}$ & $\begin{array}{c}6(4-10) \\
4(3.5-7) \\
*(\mathrm{p}=0.03)\end{array}$ & 0.6 \\
\hline $\begin{array}{c}\text { Steroids dose } \\
\text { (mg/day) } \\
\text { Before / at the end }\end{array}$ & $\begin{array}{c}10(7-12.5) \\
5(0-10)\end{array}$ & $\begin{array}{c}10(10-15) \\
5(0-10) \\
(* \mathrm{p}<0.0001)\end{array}$ & $\begin{array}{c}10(5-17.5) \\
6(1-10) \\
(* \mathrm{p}=0.01)\end{array}$ & $\begin{array}{c}7(5-10) \\
5(0-6) \\
(* \mathrm{p}=0.03)\end{array}$ & 0.06 \\
\hline
\end{tabular}

* $p$ value between values at the end and before each considered line of treatment.

Abbreviations: CRP: C-reactive protein; ESSDAI: EULAR Sjögren Syndrome Disease Activity Index; HCQ: hydroxychloroquine; RTX: rituximab 
Table 3: Comparison of HCQ, MTX and RTX for joint response (Propensity score)

\begin{tabular}{|c|c|c|c|}
\hline & & OR (IC 95\%) & p-value \\
\hline \multirow{3}{*}{ Joint non response } & MTX vs. HCQ & $1.55[0.18-13.55]$ & $\mathrm{p}=0.69$ \\
\cline { 2 - 4 } & MTX vs RTX & $5.08[0.49-52.17]$ & $\mathrm{p}=0.17$ \\
\cline { 2 - 4 } & HCQ vs. RTX & $3.28[0.28-38.02]$ & $\mathrm{p}=0.34$ \\
\hline
\end{tabular}

Non response is defined as the absence of partial and /or complete joint response.

Abbreviations: HCQ: hydroxychloroquine, MTX: methotrexate, RTX: rituximab 
Figure 1: Flow chart of the 101 treatment lines:

First line treatment: 57 patients $(\mathbf{1 0 0 \%})$

Remission: 26 patients

$(45.6 \%)$

HCQ: 12 patients

MTX: 8 patients

HCQ + MTX: 4 patients

RTX: 1 patient

Steroids alone: 1 patient
Second line treatment: 31 patients $(54.4 \%)$

Treatment failure: 24 (77.4\%)

HCQ: 13 patients

HCQ + MTX: 3 patients

MTX: 5 patients

RTX: 1 patient

Steroids alone: 2 patients

Adverse effects: 4 (22.3\%)

HCQ: 3 patients

HCQ + MTX: 1 patient

Relapse: 3 (9.7\%)

HCQ: 2 patients

Steroids alone: 1 patient
Remission: 18 patients

(58.1\%)

HCQ: 6 patients

HCQ+MTX: 2 patients

MTX: 5 patients

RTX: 3 patients

Infliximab: 1 patient

Steroids alone: 1 patient
Third line treatment: 13 patients $(41.9 \%)$

Treatment failure: $6(46.2 \%)$ HCQ: 1 patient HCQ+MTX: 1 patient MTX: 1 patient RTX: 2 patients Etanercept: 1 patient Adverse effects: 7 (53.8\%)

Steroids alone: 2 patients HCQ+MTX: 1 patient MTX: 1 patient RTX: 2 patients Belimumab 1 patient
Remission: 10 patients (76.9\%) HCQ + MTX: 3 patients RTX: 5 patients Azathioprine: 1 patient Belimumab: 1 patient
Treatment failure: 3 patients $(23.1 \%)$

Rituximab: 2 patients

Infliximab: 1 patient 